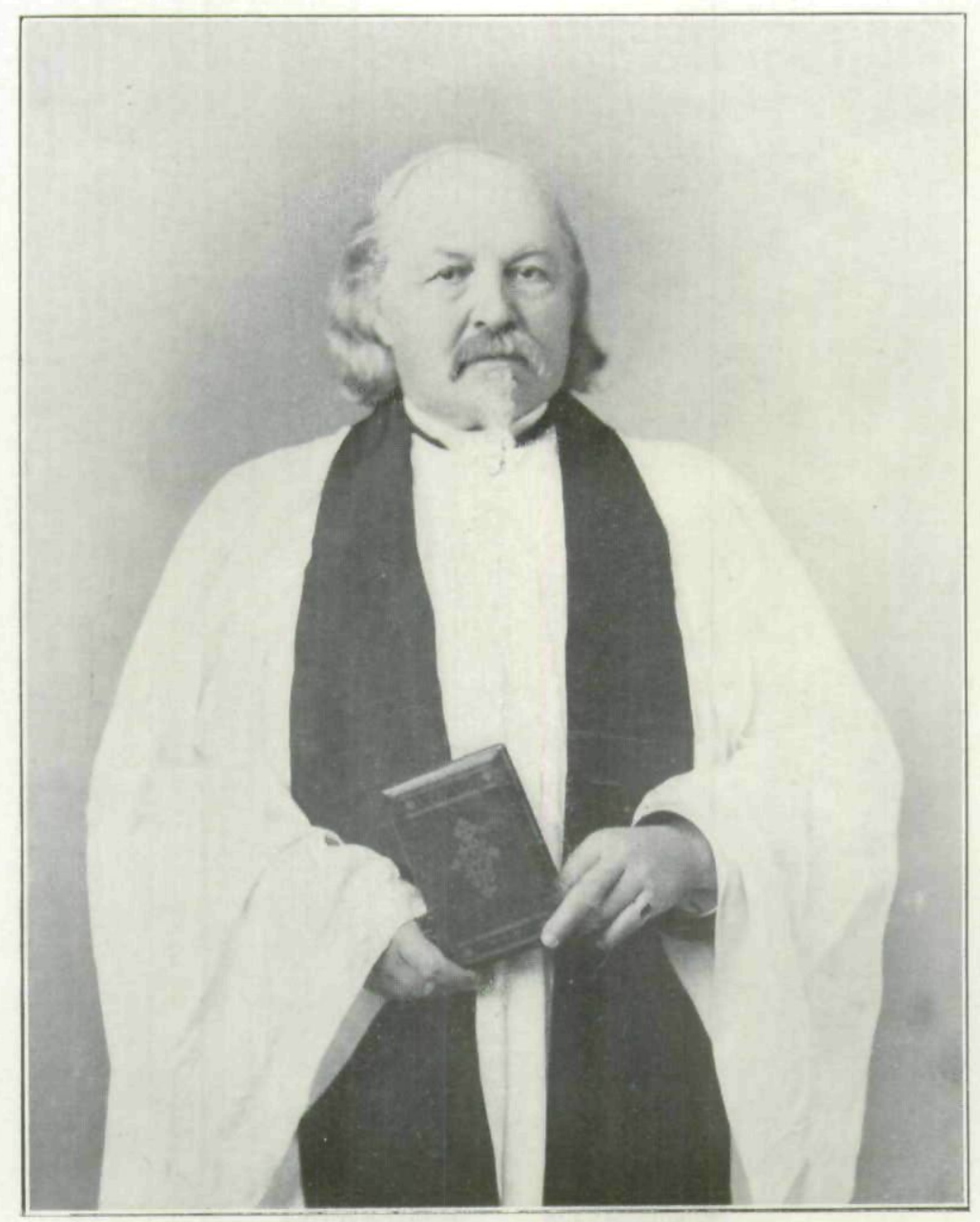

Ascot Sincuely Gouns, Irenzeis Bmesson fuche. 


\section{ESTABLISHMENT OF THE DIOCESE OF IOWA, PROTESTANT EPISCOPAL CHURCH OF AMERICA.}

BY REV. FRANCIS E. JUDD, D. D, ${ }^{1}$

When the Rector of St. Luke's Church, Rev. Henry Wash-ington Lee, Rochester, New York, received intelligence of his election to the Episcopate as the "First Bishop of Iowa", necessarily a new interest was awakened in the geographical position of his proposed diocese. Upon examining the map he found to his surprise that the extreme southeast county of the State of Iowa bore his name "Lee", and greater became his astonishment upon diseovering that the two counties lying north of "Lee" were called respectively, "Henry" and "Washington", thus inscribing on the map his indexed name. No wonder that he was somewhat impressed by this singular coincidence to which he sometimes referred, half jocularly perhaps, as providentially indicating that he ought to accept the diocese thus geographically assigned to him. Certainly, the result proved that he was rightly guided in this most important decision in his useful life; for as a pioneer missionary bishop in a widely-extended, and, in many respects, very difficult field of labor, he was always earnest, self-denying, helpful, and favored with such success as under the cireumstances was possible.

Henry Washington Lee was born in Hamden, Connecticut, on the 29th of July, 1815. His father Boswell Lee, whose native place was Spencertown, New York, was the worthy representative of a family whose name is illustrious in the annals of the Revolution, and as an evidence of the confidence

\footnotetext{
${ }^{1}$ Rev. Francis Emerson Judd, D. D.. principal of the preparatory department of Griswold College, Davenport, Iowa, 1859: Rector of Trinity Chureh, Davenport, 1860-66; President of the Standing Committee, Secretary of the Diocesan Convention, Delegate to the General Convention of 1895 , etc. His active work in Iowa extended over a period of more than forty years. He died in Portland, Ore., Feb, 25, 1902.
} 
placed in his integrity and ability, held the position of Superintendent of the Armory at Springfield, Mass., for nineteen years. He had in all eight children who lived to maturity. His removal to Springfield took place during the infancy of Henry, and brings to the mind of the writer, one of those pleasantries in conversation with which the Bishop was wont to enliven any social circle of which he happened to be a member.

At a little clerical gathering in honor of one who had exchanged his cure in Iowa for a charge in Connecticut, but had returned to his former home for a brief visit, the brethren were relating some of their parochial experiences. The visitor prefaced a story he was about to tell with the remark that perhaps he ought not to proceed, as what he had to say was not creditable to the Bishop's native State. "Don't spoil your story for relation's sake," exclaimed the Bishop, "It is true I was born in Connecticut, but I removed to Massachusetts when I was six months old and took my mother with me!"’

On the twenty-seventh day of May, 1838, in Grace Church, New Bedford, Massachusetts, the future Bishop of Iowa was ordained "Deacon" by the venerable Bishop Griswold, for whom he entertained a deep affection and profound respect. Having passed his examination with great credit, at the conclusion of his diaconate in New Bedford, he was advanced to the priesthood, October 8,1839 , being ordained by the same Bishop, at a service held in St. Anne's Church, Lowell, Massachusetts. He was called to the rectorship of Christ Church, Springfield, Mass., and on the second day of April, 1840, entered upon his duties, which for three years were discharged so faithfully that his good report reached the ears of the vestry of St. Luke's Church, Rochester, New York. He accepted a call from this large and influential parish, and was its beloved and suceessful rector for eleven years.

He received the degree of D. D. from Hobart College in 1850, and from the University of Rochester in 1852. In the year 1867 the degree of LL. D. was conferred upon the first Bishop of Iowa by the University of Cambridge, England. 
While yet a deacon, in 1839, Henry Washington Lee, of New Bedford, Mass., was united in the bonds of holy matrimony to Lydia Mason Morton, of Taunton, Mass., daughter of Gov. Mareus Morton, a union dissolved by death after thirty-five years of exceptional domestic happiness.

The first convention of the Protestant Episcopal Chureh in Iowa convened on May 31, 1854, in a church building kindly loaned for the occasion by the Presbyterians of Davenport, and was presided over by the venerable Bishop Jackson Kemper in whose missionary jurisdiction the State of Iowa was then included. In concluding his annual report the Bishop thus addressed the assembled clergymen and delegates:

As you are now fully organized, you will be anxious to enjoy every privilege and at the earliest possible day to secure to yourselves a diocesan. I will cordially co-operate with you in such efforts, and will rejoice to welcome another bishop in the West. Seek out a man of God, one who is earnest and single-minded, one who is patient of fatigue, ready to endure hardship with a cheerful spirit, for the Redeemer's sake, and who will consecrate all his energies to the work before him, which unquestionably will be the building up of the diocese in strength and holiness.

On Thursday, June 1, 1854, the election took place, Dr. Henry Washington Lee of Rochester, New York, receiving a majority of both elerical and lay ballots. Certainly, the man thus called to preside over the Diocese of Iowa as its first bishop, fully answered to the ideal presented by the words of good Bishop Kemper.

He was consecrated in St. Luke's Church, Rochester, on St. Luke's Day, Wednesday, October 18, 1854, the Bishop of Vermont presiding, and the Bishops of Michigan, Western New York, Massachusetts, Maine and Illinois being present and assisting. Bishop Eastman of Massachusetts preached the sermon.

Dr. Lee remained in charge of St. Luke's until January 1, 1855, when was severed the strong tie which for precisely eleven years had bound him to a faithful and beloved people. But before this resignation the Bishop visited his diocese, arriving at Dubuque Saturday, October 28, and on Sunday, October 29, preached for the first time in Iowa, in St. John's 
Church of that eity, of which the Rev. Robert D. Brooke was the devoted pioneer rector. His sermons, both morning and evening, produced a deep impression, and all who heard them pictured a bright future for the diocese presided over by a man so prepossessing in appearance, so attractive in discourse, and above all, so fully consecrated to his work. The Bishop visited Muscatine, Davenport and Burlington, leaving for the east on the 8th of November. In Trinity Church, Davenport, for the first time he administered the rite of confirmation. This short visit to Iowa seemed an earnest of great good in the future, so favorable were the impressions everywhere made by the Bishop in both his official and social intercourse with the people.

On Sunday, December 24, it was the delightful privilege of Bishop Lee to confirm thirty-five of the flock, which as pastor for eleven years he had cared for and loved, and on the Sunday following with mingled emotions of regret and gratitude he took leave of his beloved parishioners.

The second annual convention of the diocese of Iowa, being the first one which Bishop Lee presided over, was held in Christ Church, Burlington, of which the Rev. F. R. Hoff was the devoted and successful rector. The Bishop preached the sermon, after which the Rev. George W. Watson, deacon, was admitted to the order of priests. In his convention address the great importance of a diocesan fund for the support of the episcopate was spoken of as having been so effectually urged upon his attention that he entered at once upon the arduous task of raising it, and in so doing made a tour of the more wealthy eastern parishes. As the final result of his most successful efforts, "The Iowa Episcopate Fund" amounted to $\$ 7,933.74$, with which 6488 80-100 acres of desirable land were purchased and held for sale. This fund has provided for the erection of a handsome residence for the Bishop in Davenport, eosting over $\$ 20,000$, and also furnished investments yielding an annual income of over $\$ 3,000$. Thus. Bishop Lee's wisdom and thoughtful foresight are kept in perpetual remembrance by a grateful diocese. 
On Saturday, October 27, 1855, the Bishop returned from his eastern tour of solicitation, accompanied by his family, and made Davenport his home. Thenceforth from time to time he visited the various parishes, missionary stations, and in fact every accessible portion of the State in which any encouragement for Church work was offered. How arduous were his labors, only they whose experience realized the difficulties of travel in Iowa before the days of railroads can know; but the robust health and untiring energy of the Missionary Bishop never gave way, however great the diffieulties encountered. We can appreciate what he found in the country, when, in the eity of his residence, Davenport, while attempting to eross Second Street near the foot of Brady, he sank so deep in the mud that passers-by hastened to his assistance and pulled him out. Being a large man, six feet in height and weighing over two hundred and eighty pounds, he met with frequent disasters while traveling, breaking carriages on the road, and chairs and bedsteads in the houses where he was entertained. He had many amusing stories to relate regarding these mishaps.

In accordance with canonical requirement, in the third year of his episcopate, Bishop Lee addressed to the elergy of his diocese his primary charge, taking as its subject "Sanctification, as a Doctrine, and as a Personal Attainment". In this charge, as in fact in all his sermons and addresses, one cannot fail to be impressed with his earnest faith and deep spiritual experiences, so continuously and so forcibly was he accustomed to emphasize the infinite importance and blessedness of the "likeness to Christ." In closing this primary charge he says:

It will be my chief ambition to be known and recognized among all Christian people, as a faithful preacher of the Gospel, and as a bishop who is determined in his great work to know nothing "save Jesus Christ and Him crucified." Whether God shall permit me to devote a long life to this He only knows, but be my time of labor long or short, I am determined to consecrate it to the truest and highest interests of our beloved Zion, and if, when my work shall be done, and the scenes of time are passing away, I shall be privileged to behold here a spiritual building, fitly framed together, resting upon a true foundation, and growing into a holy temple to 
the Lord, I shall depart in peace. But if, in that solemn hour, I shall be doomed to look upon the diocese to which my best days and best services have been devoted, and see its light dimmed and its glory tarnished by a worldly-minded people under the lead of an unsanctified ministry, I should go down with sorrow to the grave. May God make us a holy Church! May we as a diocese become eminent in spirituality! May we be of one heart and mind in the great work entrusted to our hands, striving together in the faith of the gospel! Brethren, the time is short! Soon our work will be finished and others will enter into our labors. 0 , then, be faithful: Be faithful unto death, if you would have a crown of life.

These words declare eloquently the Bishop's keen sense of personal responsibility to the Divine Master.

On the Eighth Sunday after Trinity, July 13, 1856, by the invitation of Bishop Kemper, Bishop Lee preached in Omaha City the first sermon by a Church Bishop in the Territory of Nebraska. At that time the Rev. George W. Watson divided his most suceessful ministry between Council Bluffs, Iowa, and Omaha City. Bishop Lee left Oskaloosa on Monday, July 7, and was joined by Bishop Kemper at Fort Des Moines. He reached Council Bluffs on Friday, July 11, thus having been five days on the journey.

In his address to the sixth annual convention, on May 30, 1860, the Bishop announced the purchase of what was then known as the "Iowa College" property in the city of Davenport. Iowa College had been moved to Grinnell and the entire property, consisting of two city squares, with a large college building built of stone, and a frame boarding house, was purchased for $\$ 36,000$, the contract having been made with the Bishop individually. Possession was taken on the first day of August and the Bishop said: "To myself it was an interesting circumstance that this full and final decision to purchase the 'Iowa College' property was made on my forty-fourth birthday, July 29th'.

A semi-annual convocation was held at Davenport, December 6-8, in connection with the services of which, a college corporation was organized and the name of the late presiding Bishop Griswold was unanimously adopted as that of the institution. In his sixth annual address already referred to, Bishop Lee paid Bishop Griswold this tribute: 
From this now sainted man I received the holy rite of confirmation, and by him I was admitted to the diaconate and the priesthood, and I have ever regarded him as one of the wisest and purest prelates that ever adorned our Church, or the Mother Church of England.

On Dec. 12, 1859, the preparatory department of Griswold College was opened under the charge of the Rev. Francis Emerson Judd, M. A., who for this purpose at the Bishop's request, resigned the rectorship of St. Michael's Church, Mount Pleasant. He was assisted by Prof. D. S. Sheldon, late of Iowa College, and the institution opened with over thirty pupils. The following spring found Bishop Lee in the East raising funds for the college and meeting with his usual success.

The eighth annual convention of the Diocese of Iowa convened in Dubuque, May 29, 1861, and in his address the Bishop spoke most earnestly and with intense loyalty regarding the fearful dangers threatening the commonwealth and the grave responsibilities resting upon its eitizens. $\mathrm{He}$ said in conclusion:

While I thus speak out of the fullness of a heart that grieves and agonizes over the darkened hopes and purposes of our beloved country, and while as a Christian and a Christian teacher, I mourn over the deep and awful corruption of man's nature, which has so long resisted the combined influences of civilization and religion, I cannot yet do otherwise than exhort both elergy and people to defend the nation's honor and uphold the nation's laws. As the world is, wars and commotions must needs be; and in spite of their incompatibility with the pure principles of the Gospel of Christ, we will believe, that God, in His wise providence, will bring good out of evil and extend His Kingdom among the ruins of nations and empires. Even the present troubles and afflictions of our country undoubtedly will be overruled to the furtherance of those divine plans which render certain the final, though gradual triumph of civilization and Christianity.

He also adds :

Nor can I refrain from giving utterance to a desire long-continued, and now greatly increased, and not inconsistent with charity towards those who hold widely different sentiments, that in God's own time, by means which he can approve, the social and domestic institution (slavery) which has so plagued, and irritated, 
and divided us as a nation, may be removed from human society, and take its place, side by side in the history of the world, with bad and obsolete systems of human government, and with other things which God has winked at, or permitted, but never commended or sanctioned, as His own chosen and permanent appointments among the children of men.

The good Bishop lived to see this philanthropic desire most fully and gloriously accomplished.

In October, 1862, Bishop Lee attended the General Convention of the Church assembled in New York, of which he thus speaks in his ninth annual address at Iowa City, May 27, 1863 :

The principal discussions in this Council of the Church had reference to the unhappy condition of our country, especially in, its bearing on our ecclesiastical affairs, and the final action of both houses was singularly accordant with that of our own diocesan convention eighteen months before. The general tenor of my own remarks on this subject, in the conventional address of 1861 , and the unanimous resolution of the convention itself, may be regarded as having been virtually sanctioned by the Chureh at large. Our Church has ever and wisely stood aloof from entangling alliances and unboly intermeddling with political parties and party politics, but in the awful crisis through which the nation is passing, she has faithfully echoed the voice of Holy Writ, as to the duty of Christian people to the civil authority; and uttered her firm but kind remonstrance in opposition to all that hasty and premature action by which our brethren in the seceding states have sought to divide the Church, before the great question of civil division is determined and settled according to the usages of the nations of the earth.

During the continuance of the war Bishop Lee set forth suitable prayers to be used on the duly appointed national fast days, and on April 17, 1865, he issued a pastoral letter to the diocese having reference to the tragic and untimely death of President Lincoln; setting forth also a suitable prayer to be used on the day of humiliation and fasting appointed by the Governor of the State in consequence of the sad event. ${ }^{2}$ On the day of the obsequies in Washington, April 19th, Bishop Lee took part in solemn funeral services held in the chapel of Griswold College, in honor of the de-

\footnotetext{
2Proclamation on the Death of Abraham Lincoln, by Gov. W. M. Stone,
April 15, 1865 .
} 
ceased President, at which the Rev. H. N. Powers ${ }^{3}$ delivered an appropriate and eloquent discourse. On every occasion and in every emergency when he could exert an influence, either officially or privately, for the good of his country, Bishop Lee always proved himself a wise and true patriot; a worthy descendant of the heroes of the Revolution.

On August 14, 1867, the Bishop of Iowa sailed for England, and having arrived safely was present at all the sessions of the Pan-Anglican Conference in Lambeth Palace. He afterwards made a tour through England, Ireland and Scotland, visiting also the most interesting portions of France and Switzerland. He made several addresses, one of them at the Church Congress at Wolverhampton, and preached ten times in England, once in Ireland and twice in Paris. Unfortunately, he was compelled by indications of failing health to return home sooner than he desired, but he enjoyed the European sojourn exceedingly. In his convention address of 1868 he thus speaks of it:

It afforded me rare and precious opportunities of social and official intercourse. I visited places and objects of the deepest historical interest, and received impressions especially respecting England and its Church which I trust will be of great use to me the rest of my life.

In this same address, referring to the ritualistic practices then agitating ecclesiastical circles in England, and regarding which he had written an open letter to the Bishop of London he thus concludes:

Notwithstanding our existing differences and troubles, I look for returning unity, peace and concord, and for a fulfillment of that great and glorious destiny which would seem to be awaiting us as a Church; a destiny foreshadowed by our essential primitive features, by our evident and peculiar mission in this land, by our past history, and by that wise system of means and instrumentalities so admirably adapted to maintain the true worship and word of God, and to extend pure and undefiled religion among all mankind.

\footnotetext{
${ }^{3}$ Rev. Horatio Nelson Powers, D. D., was born in Amenia, N. Y., April 30, 1826 ; he died in Plermont, N. Y., Sept. 6,1890 . He was educated in Union College and the General P. E. theological seminary in New York, and was ordained as a deacon of Trinity Church. He was rector of St. Luke's Church, Davenport, Iowa, $1857-62$ and president of Griswold College in 1864-67.
} 
These words recall another very frequent utterance of the Bishop:- "Our Church is the balance-wheel of American Society."

The annual address of 1868 thus concluded (he had just before spoken of the death of the venerable Bishop Hopkins of Vermont) :

My dear Brethren we are all passing away, and soon we shall close our earthly stewardship and go to our final account. I feel more deeply than ever the awful responsibility of the ministry of the Gospel, and of the position of all who are members of the Church of the living God. A few days since I completed thirty years of my own ministry, nearly fourteen of which have been spent in my present work as Bishop of this Diocese. I have thus labored in the divers orders of the sacred office for that entire term of years usually alloted for a generation; and as I look back over the nast, all seems like a flitting shadow and passing dream. I feel that I have accomplished little for the Master and His Kingdom, and that very limited success is now attending my labors. This may be a proper and salutary feeling, but it is certainly very humiliating and distressing and at times overwhelming. I earnestly ask your prayers that I may be more faithful in my appointed work, and more entirely devoted to Him, who is the gracious Bishop and Shepherd of our souls; assuring you from my heart, that both as ministers and people, you have my affectionate sympathy and regard, and that I shall not cease to implore the God of all grace to have you in His holy keeping, prospering your united and co-operative labors in the work of the Lord, and welcoming you at last to the rewards of faithful servants in His presence and glory on high.

The twenty-first annual convention of the Diocese of Iowa was held in Grace Cathedral, Davenport, and in his address upon that oceasion the Bishop said:

The consecration of Grace Cathedral, where we are now assembled took place on Wednesday, the 18th of June last, in the services of which most interesting occasion, I was assisted by the Bishops of Minnesota and Nebraska, and by a large number of the clergy, some of whom were from other dioceses. The Bishop of Minnesota kindly preached the consecration sermon. The building was consecrated as a cathedral at the request of the last convention, and the name "Grace" was adopted as being that of a wellknown church in the eity of New York, from members of which came the largest offerings towards its erection; though a kind-hearted individual of another parish in the same city, formerly of Chicago, originally suggested the undertaking and gave largely towards its accomplishment. 
In the same address the Bishop announces the completion of the Episcopal residence and the taking possession of it by his family. He also referred to the then recent organization of the so-called "Reformed Episcopal Church," which movement he most heartily regretted and openly condemned, in the following language:

It is based on a narrow foundation. It would seem there was no adequate excuse for such a movement, when the evils complained of could have been so much better met and remedied in the Church itself. In my opinion it was ill-advised and unfortunate. I have no harsh or unkind words, however, for those engaged in it; but I may give utterance to my deep regret and sorrow that these brethren have made so sad a mistake and taken upon themselves such a fearful responsibility. I have in another form spoken freely and somewhat at length upon this subject. My personal relations te the late Assistant Bishop of Kentucky, the leader in this movement induced me to address him a pastoral letter of remonstrance and explanation. I had been one of his consecrators, and for years an intimate friend, and $I$ feit it to be a solemn duty to put on record my decided testimony against a new and unnecessary division among those who profess and.call themselves Christians. The letter was published in our diocesan paper, and thus thas a permanent place in the records of the Church. It also appeared in various Church papers, and in the secular journals.

They who listened so attentively to their beloved Bishop's address, had indeed no thought that it would be his last. $\mathrm{He}$ seemed in his usual health and vigor, and the impressive earnestness of his speech was in no wise diminished. Yet, on the twenty-sixth day of the following September, "he fell asleep."

Notwithstanding his apparent physical strength, the Bishop had not been well for some time before he met with the accident which apparently hastened his death. Making a misstep, he fell upon the stairs of his residence and so injured his hand, that, owing to the diseased condition of his system, the result was speedily fatal. One ean hardly imagine the thrill of surprise and sorrow that ran through the diocese when the news of his death was heard. A vivid remembrance of his genial manners and unaffected earnestness filled with tears many eyes, and heartfelt messages of sympathy came from every direction, far and near to his suffering family. 
The funeral services, held in Grace Cathedral on the 29th of September, were attended not only by a large concourse of the eitizens of Davenport, but also by lay representatives from parishes throughout the State, and by the mass of his own clergy with many brethren from neighboring and other dioceses. Bishops Henry B. Whipple, of Minnesota, Charles F. Robertson of Missouri, and Thomas H. Vail of Kansas, conducted the services, the Bishop of Kansas preaching the sermon in which he paid his friend and brother an eloquent tribute of affectionate esteem.

The first Bishop of Iowa completed his twenty years of arduous and most faithful labors, labors requiring many thousand miles of travel, and a continued series of services, sermons and addresses, including also many journeys eastward, undertaken for the purpose of raising the means to carry on his numerous and important enterprises. Truly his works do follow him. "Being dead he yet speaketh." Aye, and will speak so long as the early history of the Diocese of Iowa shall be known.

At the special convention ealled by the Standing Committee and held in Grace Cathedral, Dec. 9, 1874, less than three months after the Bishop's decease, the writer by request preached a sermon commemorative of his beloved Diocesan, and perhaps he cannot conclude this imperfect sketch more fittingly than in words taken from his discourse upon that oceasion :

In material possessions our Diocese for its age is rich, and, what is of far more importance, within it the foundations of the American Catholic Church have been wisely laid broad and deep. No spirit of narrow bigotry and no effort of intolerance has ever found encouragement in the policy of the large-minded, large-hearted man, whose comprehensive views and charitable rule for twenty years have guided the development of our youthful Diocese. All Bishop Lee's writings, his letters, his sermons, his convention addresses, his pastorals and triennial charges, bear unmistakably the impress of Christ's character and teaching. These testify, each and all of them, how sacredly he regarded his consecration vow to "faithfully exercise himself in the Holy Scriptures and call upon God by prayer for the true understanding of the same." He was in every respect a representative man; showing fairly both the ecclesiastical and 
doctrinal position of that branch of the "Holy Church Universal" known for the time being as the "Protestant Episcopal Church in the United States of America."

But if Bishop Lee was eminent in all pertaining to his official position, he was also eminently Christian in the various relations of private life. As a husband and father he was tenderly thoughtful and affectionate; as a friend, considerate and true, and as an acquaintance and neighbor most sociable and charitable. His cheerful manners and entertaining conversation rendered his society universally attractive. His words of cheer and deeds of judicious but unostentatious benevolence cheered many an anxious heart and gladdened many a needy home.

\section{CAMANCHE AND ALBANY FERRY.}

The subscriber respectfully informs the traveling public, that he has in complete operation a large and commodious Ferry Boat, propelled by horse power plying between the above places, at one of the best locations for a ferry on the Mississippi, river, and on the most direct route from Chicago or in fact all the eastern travel through Iowa Territory to the settlements on Cedar, Iowa, Waubesepineca, or Macoqueta, rivers. This Boat is large and safe for teams and heavy earriages, and will land on either side of the Meridosia to accommodate passengers.-The subseriber hopes by always being in readiness to accommodate the public, to merit and receive the patronage of travellers and emigrants.

\section{JAMES CLAIBURN,} Proprietor.

Camanche, June 5, 1839.

-Iowa Sun, Davenport, November 13, 1839. 
Copyright of Annals of Iowa is the property of State of Iowa, by \& through the State Historical Society of Iowa and its content may not be copied or emailed to multiple sites or posted to a listserv without the copyright holder's express written permission. However, users may print, download, or email articles for individual use. 